\title{
Impact of budding on free-living corals at East Kalimantan, Indonesia
}

Received: 2 December 2003 / Accepted: 19 January 2004/Published online: 2 September 2004

(C) Springer-Verlag 2004

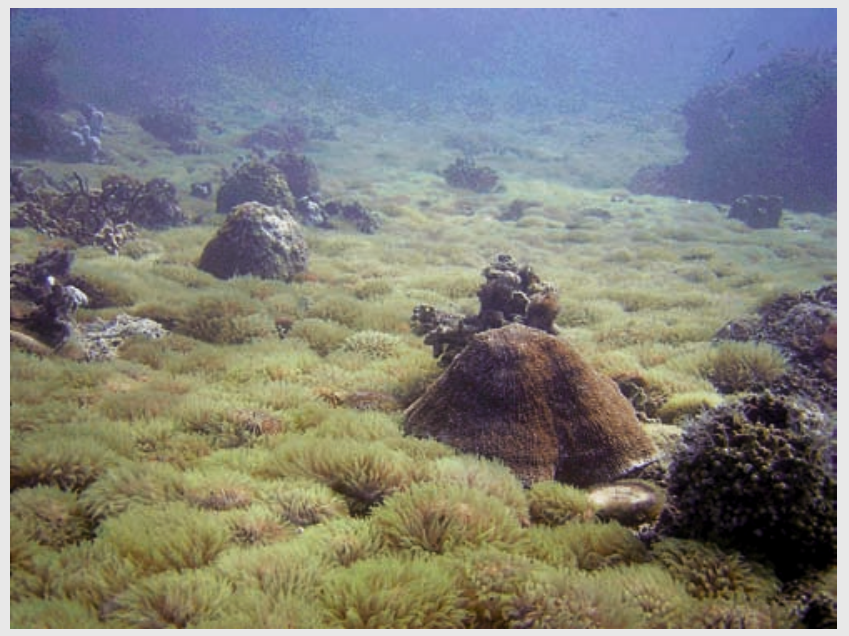

Fig. 1. A field of free-living Fungia fralinae corals. The densely and evenly dispersed disc-shaped corals have their large green tentacles extended

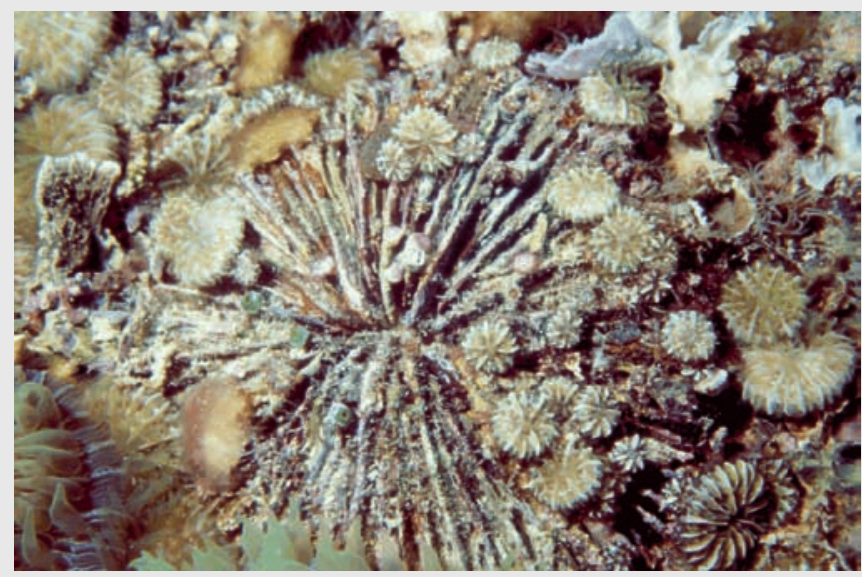

Fig. 2 A nearly dead coral of $F$. fralinae with attached buds surrounded by larger detached corals
A reef site named 'mushroom coral garden' was studied south of Derawan Island, Berau Islands $\left(118^{\circ} 15^{\prime} 08.4^{\prime \prime} \mathrm{E}, 02^{\circ} 16^{\prime} 17.5^{\prime \prime} \mathrm{N}\right)$ in October 2003. The reef slope $(8-10 \mathrm{~m})$ thin coral fragments, covered (est. $>95 \%$ ) by unattached mushroom corals (Fig. 1). Almost all individuals $\left(100 \mathrm{~m}^{-2}\right)$ belong to Fungia fralinae Nemenzo, 1955 (Hoeksema 1989). The smallest free-living individuals derived from budding and were in the proximity of senescing parent corals with younger buds still attached (Fig. 2). A few overturned individuals showed inflated soft tissue. The coral aggregation also contained fragments of Zoopilus echinatus Dana 1846 and some intact corals of Halomitra pileus (Linnaeus 1758). The well-developed capacity to expand their bodies enables $F$. fralinae individuals to disperse and to maneuver into optimal positions to catch light and food (Hoeksema 1988). This combination of budding and mobility may be crucial in explaining its local abundance pattern.

Acknowledgments The survey was sponsored by the Indonesian Institute of Sciences (LIPI), the Netherlands Organization for Scientific Research (WOTRO grant WT 87-299), the Royal Dutch Academy of Sciences (KNAW), and Derawan Dive Resort.

\section{References}

Hoeksema BW (1988) Mobility of free-living fungiid corals (Scleractinia), a dispersion mechanism and survival strategy in dynamic reef habitats. Proc 6th Int Coral Reef Symp 2:715-725

Hoeksema BW (1989) Taxonomy, phylogeny, and biogeography of mushroom corals (Scleractinia: Fungiidae). Zool Verh Leiden 254:1-195

Hoeksema BW (1990) Cross-shelf distribution patterns of mushroom corals (Fungiidae) in the southern Makassar Stait. In: Systematics and ecology of mushroom corals (Scleractinia: Fungiidae). PhD-Thesis, Leiden University, pp 361-458

Hoeksema BW (1991) Control of bleaching in mushroom coral populations (Scleractinia: Fungiidae) in the Java Sea: stress tolerance and interference by life history strategy. Mar Ecol Prog Ser 74:225-237

Littler MM, Littler DS, Brooks BL, Koven JF (1997) A unique coral reef formation on the Great Astrolabe Reef, Fiji. Coral Reefs 16:51-54

\section{B. W. Hoeksema}

National Museum of Natural History Naturalis, P.O. Box 9517, 2300 RA Leiden, The Netherlands

E-mail: Hoeksema@naturalis.nnm.nl

Tel.: + 31-71-5687631

Fax: + 31-71-5687666 